\title{
Fatal rupture of pulmonary artery pseudoaneurysm after thoracic radiation therapy against lung squamous cell carcinoma: a case report and literature review
}

\author{
Yosuke Fukuda ${ }^{1}$, Tetsuya Homma ${ }^{2}$, Tomoki Uno ${ }^{1}$, Yasunori Murata ${ }^{1}$, Eisuke Shiozawa ${ }^{3}$, \\ Shintaro Suzuki ${ }^{1}$, Masafumi Takimoto ${ }^{3}$, and Hironori Sagara ${ }^{2}$ \\ ${ }^{1}$ Showa University School of Medicine, Department of Medicine, Division of Respiratory \\ Medicine and Allergology \\ ${ }^{2}$ Showa University School of Medicine \\ ${ }^{3}$ Showa University School of Medicine, Department of Pathology
}

May 18, 2020

\begin{abstract}
Rupture of pulmonary artery pseudoaneurysm (PAP) can result in life-threatening hemoptysis. A 65-year-old male was diagnosed with PAP based on chest contrasted computer tomography (CT). He coughed up massive amounts of blood and could not be resuscitated. In the autopsy, macroscopic and microscopic findings supported the clinical course.
\end{abstract}

Introduction

Hemoptysis is often a life-threatening symptom and may cause severe clinical conditions. Causes of hemoptysis are varied, and include bronchiectasis, infection (e.g., tuberculosis, pneumonia, fungal infection), trauma, pulmonary vascular disease, iatrogenic injuries, and airway malignancies 1-4. Pulmonary artery pseudoaneurysm (PAP) is a rare cause of hemoptysis, but careful consideration should always be given as it is potentially fatal. In fact, there have been several reports on the occurrence of PAP during radiation therapy against lung cancer. We encountered a 65-year-old male lung cancer patient with hemoptysis due to rupture of PAP induced by thoracic radiation therapy (TRT). An autopsy was performed and we herein report the detailed clinical, radiological, and pathological findings. Written informed consent was obtained from his relatives.

Case report

A 65-year-old male was diagnosed with lung squamous cell carcinoma and TRT at 60 Gy total in 30 daily fractions was started. Nausea and vomiting were present at the end of the therapy. Decreased breathing sounds was observed in the upper left side of the chest where TRT had been performed. The laboratory results showed white blood cell (WBC) count of $15,100 / \mathrm{mm}^{3}$ and C-reactive protein (CRP) level of $16.14 \mathrm{mg} / \mathrm{dl}$. Chest CT revealed consolidation and cavity in the left upper lobe. He was thus diagnosed as lung abscess and treated with the intravenous antibiotics, meropenem, for three weeks. His clinical and radiographic findings consequently showed improvement. However, he had hemoptysis after the antibiotic treatment and intravenous contrasted chest CT revealed left PAP (Figure 1). He coughed up a massive amount of blood before his scheduled PAP-embolization and could not be resuscitated due to airway occlusion.

Autopsy was performed on the next day after death. Macroscopic findings showed cavity in the left upper 
lobe leading to the left pulmonary artery and whole lung edema was observed (Figure 2A, 2B). Moreover, blood coagulation was found in the trachea and main bronchus (Figure 2C). Microscopic findings showed that the arterial wall had been damaged with fibrin drainage based on Elastica van Gieson stain (Figure 3A, 3B). The lung abscess wall included squamous cell carcinoma cells (Figure 3C).

\section{Discussion}

Although the rate of PAP occurrence is rare, bronchiectasis, infection, trauma, iatrogenic, vascular disease, and airway malignancy are its major causes 1-3. Pseudoaneurysm is defined as focal blood vessel dilation that does not involve all arterial wall layers, while aneurysm is defined as that which involves all three arterial wall layers 5. The precise mechanism of PAP formation has not yet been elucidated. In our current case, microscopic findings showed arterial wall disruption by inflammation together with invasion of squamous cell carcinoma, which affected the adventitia and the tunica media (Figure 3A). Boerrigter et al recently proposed that structural changes of elastin and collagen under the influence of an increasing PA pressure may lead to PA dilation and further PAP formation 6. This disruption and the abnormal formation of the arterial vessel may be further exacerbated by radiation therapy.

Since PAP is a fatal condition, prompt and appropriate diagnosis is essential in the clinical setting. Although pulmonary angiography is the gold standard for PAP diagnosis 7- 9, contrast-enhanced CT enabled PAP diagnosis with less invasiveness 10. AP is defined as an upper limit of the main pulmonary artery (PA) diameter $(29 \mathrm{~mm})$ and an upper limit of the right interlobar artery $(17 \mathrm{~mm})$ measured using CT images 10 . The present case fulfilled this criteria (upper limit of the main PA diameter was $31 \mathrm{~mm}$ and upper limit of the right interlobar artery was $19 \mathrm{~mm}$ ). In past reports, maximum intensity projection (MIP) and multi planar reconstruction images on CT have been useful for PAP diagnosis 11.

Previous literature has indicated that lung cancer is associated with PAP formation 12-20. In cases with lung cancer-associated PAP, it is possible that tumor invasion to blood vessels may result in PAP formation 14. To the best of our knowledge, there have been twelve cases of pseudoaneurysm accompanied with lung cancer and squamous cell carcinoma was the most frequent in the reported cases (Table 1). Six patients survived without any intervention, while four patients died (two were unknown). It is well known that lung squamous cell carcinoma characteristically presents with hemoptysis 21 . Razazi et al reported that 125 patients had hemoptysis related to non-small cell lung carcinoma, and in those patients, the proportion of squamous cell carcinoma was $52 \% 21$. Moreover, tumor cavitation during cancer treatment has been suggested as a risk factor for hemoptysis 21 . In the present case, we hypothesize that PAP caused by squamous cell lung carcinoma together with a tumor cavity may be a significant risk factor for massive hemoptysis.

Additionally, radiation therapy is known to cause vascular diseases including PAP 22. Schultz et al reported radiation therapy causes acute up-regulation of pro-inflammatory cytokines and adhesion molecules in the endothelium that recruits inflammatory cells to the sites of vascular injury 23. Martin et al subsequently proposed a mechanism of radiation-induced vascular disease whereby resultant oxidative stress causes nuclear factor-kappa B (NF- $\chi \mathrm{B})$ activation that in turn causes inflammatory cytokine up-regulation 24 . Moreover, pre-existing cardiac disease has been significantly associated with development of cardiac events in lung cancer patients who have received radiation therapy. In Netherlands, $23 \%$ lung cancer patients had developed cardiovascular disease 25. In Table1, four patients had received radiation therapy for lung cancer treatment before PAP diagnosis (two had received combined chemotherapy with radiation therapy, and two including our case had received radiation therapy alone). As with these cases, there was possibility that PAP development was accelerated by radiation therapy in our case.

Endovascular and percutaneous interventional procedures are often used for PAP treatment. Percutaneous intervention is a less invasive option than surgical treatment. While the primary intervention is the embolization of systemic arteries, other therapeutic options may be considered depending on the size and location of the PAP 10. Unfortunately the current case had died from massive hemoptysis before receiving intervention therapy.

Conclusions 
In summary, we encountered a lethal clinical course of pulmonary artery pseudoaneurysm after thoracic radiation therapy against lung squamous cell carcinoma. It is important to note that PAP could be a fatal cause. In patients with hemoptysis or bloody sputum, it is critical to detect and diagnose PAP, and if present, to conduct timely and appropriate interventional therapy.

Acknowledgements

The authors gratefully acknowledge the support of the medical staff of Department of Pathology at Showa University Hospital for great assistance and contributions for our study.

Author contributions

Conceptualization: Yosuke Fukuda

Investigation: Tomoki Uno, Yasunori Murata, Shintaro Suzuki

Supervision: Tetsuya Homma, Eisuke Shiozawa, Masafumi Takimoto

Writing - original draft: Yosuke Fukuda

Writing - review \& editing: Hironori Sagara

References

1 Corder R. Hemoptysis. Emerg Med Clin North Am . 2003;21:421-435.

2 Nguyen DV, Murin S. Bronchial artery pseudoaneurysm with major

hemorrhage after bronchial thermoplasty. Chest. 2016;149:e95-97.

3 Oguma T, Morise M, Harada K, et al. Pulmonary artery aneurysm/pseudoaneurysm, a delayed complication of lung abscess: A case report. Tokai J Exp Clin Med. 2015;40:86-89.

4 Lafita V, Borge MA, Demos TC. Pulmonary artery pseudoaneurysm: etiology, presentation, diagnosis, and treatment. Semin Intervent Radiol. 2007;24:119-123.

5 Kreibich M, Siepe M, Kroll J, Höhn R, Grohmann J, Beyersdorf F. Aneurysm of the pulmonary artery. Circulation. 2015;131:310-316.

6 Boerrigter B, Mauritz GJ, Marcus JT, et al. Progressive dilation of the main pulmonary artery is a characteristic of pulmonary arterial hypertension and is not related to changes in pressure. Chest . 2010;138:13951401.

7 Theodoropoulos P, Ziganshin BA, Tranquilli M, Elefteriades JA. Pulmonary artery aneurysm: four case reports and literature review.Int $J$ Angiol. 2013;22:143-8.

8 Shin TB, Yoon SK, Lee KN, et al. The role of pulmonary CT angiography and selective pulmonary angiography in endovascular management of pulmonary artery pseudoaneurysms associated with infectious lung diseases. J Vasc Interv Radiol. 2007;18:882-887.

9 Khalil A, Parrot A, Nedelcu C, Fartoukh M, Marsault C, Carette MF. Severe hemoptysis of pulmonary arterial origin: signs and role of multidetector row CT angiography. Chest. 2008;133:212-219.

10 Nguyen ET, Silva Cl, Seely JM, Chong S, Lee KS, Muller NL. Pulmonary artery aneurysms and pseudoaneurysms in adults: findings at CT and radiography and pseudoaneurysm. Am J Roentgenol.2007;188:126134.

11 Haranaga S, Teruya H, Nakamura H, Higa F, Tateyama M, Fujita J. Pulmonary artery pseudoaneurysm secondary to lung abscess. Intern Med. 2009;48:2159-2160. 
12 Akpinar E, Turkbey B, Canyigit M, et al. Bleeding pulmonary artery pseudoaneurysm secondary to squamous cell lung cancer: computer tomography findings and endovascular management. Acta Radiol.2006;47:944-946.

13 Kim SY, Kim HR, Song JS, et al. Pseudoaneurysm due to squamous cell carcinoma of the lung: two cases of spontaneous resolution after chemotherapy. Cancer Res Treat. 2009;41:237-240.

14 Camargo Jde J, Camargo SM, Machuca TN, Bello RM. Large pulmonary artery pseudoaneurysm due to lung carcinoma: pulmonary artery aneurysm.J Thorac Imaging. 2010;25:4-5.

15 Bao M, Zhou Y, Jiang G, Chen C. Pulmonary artery pseudoaneurysm after a aleft upper sleeve lobectomy. World J Surg Oncol. 2013;11:272.

16 T Miyazaki, N Yamasaki, T Tsuchiya, et al. Surgical resection of a pulmonary artery pseudoaneurysm after middle lobectomy: Report of a case. Acta Med Nagasaki. 2014;60:25-27.

17 Kim YI, Kang HC, Lee HS, et al. Invasive pulmonary mucormycosis with concomitant lung cancer presented with massive hemoptysis by huge pseudoaneurysm of pulmonary artery. Ann thorac Surg. 2014;98:18321835 .

18 Kim JH, Han SH. A pulmonary artery pseudoaneurysm caused by concurrent chemoradiation therapy for lung cancer. Pak J Med Sci . 2015;31:220-222.

19 Zhang J, Jiang S. Massive hemoptysis from a central pulmonary arterial pseudoaneurysm secondary to advanced cancer: successful treatment by Gugliemi detachable coil embolization. Clin Respir J . 2017;11:258262.

20 Chen Y, Gilman MD, Humphrey KL, et al. Pulmonary Artery Pseudoaneurysm: Clinical Features and Ct Findings. AJR Am J Roentgenol. 2017;208:84-91.

21 Razazi K, Parrot A, Khalil A, et al. Severe haemoptysis in patients with nonsmall

cell lung carcinoma. Eur Respir J. 2015;45:756-764.

22 Weintraub NL, Jones WK, Manka D. Understanding radiation-induced vascular disease.J Am Coll Cardiol. 2010:55:1237-1239.

23 Schultz-Hector S, Trott KR. Radiation-induced cardiovascular diseases: is the epidemiclogic evidence compatible with the radiobiologyic data? Int Radiat Oncol Biol Phys. 2007;67:10-18.

24 Halle M, Gabrielsen A, Paulsson-Berne G, et al. Sustained inflammation due to nuclear factor-kappa B activation in irradiated human arteries. J Am Coll Cardiol. 2010;55:1227-1236.

25 Janssen-Heijinen ML, Schipper RM, Razenberg PP, Crommelin MA, Coebergh JW. Prevalence of comorbidity in lung cancer patients and its relationship with treatment: a population-based study. Lung Cancer. 1998;21:105-113.

Table 1.

Table1. Cases with pulmonary artery pseudoaneurysm due to cancer.

\begin{tabular}{llllll}
\hline & & \multicolumn{5}{c}{ Initial treatment } \\
Case No. & Age/Sex & Histology & occurrence & $\begin{array}{l}\text { Clinical } \\
\text { Outcome }\end{array}$ & Ref \\
\hline 1 & $55 \mathrm{M}$ & $\mathrm{Sq}$ & none & $\begin{array}{l}\text { Survived (Coil } \\
\text { embolization) }\end{array}$ & $\begin{array}{l}\text { Akpinar E } \\
\text { (2006) 12 }\end{array}$ \\
2 & & Sq & none & $\begin{array}{l}\text { Survived (Coil } \\
\text { embolization) }\end{array}$ & $\begin{array}{l}\text { Kim SY } \\
\text { (2009) 13 }\end{array}$
\end{tabular}




\begin{tabular}{|c|c|c|c|c|c|}
\hline Case No. & Age/Sex & Histology & $\begin{array}{l}\text { Initial treatment } \\
\text { before PAP } \\
\text { occurrence }\end{array}$ & $\begin{array}{l}\text { Clinical } \\
\text { Outcome }\end{array}$ & Ref \\
\hline 3 & $66 \mathrm{M}$ & $\mathrm{Sq}$ & none & Survived (CT) & $\begin{array}{l}\text { Kim SY } \\
(2009) 13\end{array}$ \\
\hline 4 & $54 \mathrm{M}$ & $\mathrm{Sq}$ & none & $\begin{array}{l}\text { Survived } \\
\text { (Sleeve } \\
\text { lobectomy) }\end{array}$ & $\begin{array}{l}\text { Camargo Jde } \\
\mathrm{J}(2010) 14\end{array}$ \\
\hline 5 & $55 \mathrm{~F}$ & $\mathrm{Sq}$ & $\begin{array}{l}\text { Sleeve } \\
\text { lobectomy }\end{array}$ & $\begin{array}{l}\text { Survived } \\
\text { (Complete } \\
\text { pneumonectomy) }\end{array}$ & $\begin{array}{l}\text { Bao M (2013) } \\
15\end{array}$ \\
\hline 6 & $76 \mathrm{~F}$ & unknown & $\begin{array}{l}\text { Sleeve } \\
\text { lobectomy }\end{array}$ & $\begin{array}{l}\text { Survived } \\
\text { (Sleeve } \\
\text { lobectomy) }\end{array}$ & $\begin{array}{l}\text { T Miyazaki } \\
(2014) 16\end{array}$ \\
\hline 7 & $66 \mathrm{M}$ & $\mathrm{Sq}$ & none & $\begin{array}{l}\text { Death (Coil } \\
\text { embolization) }\end{array}$ & $\begin{array}{l}\text { Kim YI (2014) } \\
17\end{array}$ \\
\hline 8 & $64 \mathrm{M}$ & $\mathrm{Sq}$ & $\mathrm{CT}+\mathrm{TRT}$ & $\begin{array}{l}\text { Death (No } \\
\text { intervention) }\end{array}$ & $\begin{array}{l}\text { Kim JH (2015) } \\
18\end{array}$ \\
\hline 9 & $66 \mathrm{M}$ & $\mathrm{Sq}$ & $\mathrm{CT}+\mathrm{TRT}$ & $\begin{array}{l}\text { Death (Coil } \\
\text { embolization) }\end{array}$ & $\begin{array}{l}\text { Zhang J } \\
\text { (2017) } 19\end{array}$ \\
\hline 10 & $65 \mathrm{M}$ & $\mathrm{Sq}$ & TRT & $\begin{array}{l}\text { Death (No } \\
\text { intervention) }\end{array}$ & Our Case \\
\hline 11 & $65 \mathrm{M}$ & $\mathrm{Sq}$ & TRT & unknown & $\begin{array}{l}\text { Chen Y (2017) } \\
20\end{array}$ \\
\hline 12 & $68 \mathrm{M}$ & $\mathrm{Sq}$ & $\begin{array}{l}\text { Sleeve } \\
\text { lobectomy }\end{array}$ & unknown & $\begin{array}{l}\text { Chen Y (2017) } \\
20\end{array}$ \\
\hline
\end{tabular}

$\mathrm{Sq}=$ squamous cell carcinoma, $\mathrm{CT}=$ chemotherapy, $\mathrm{PAP}=$ pulmonary pseudoaneurysm, Ref $=$ reference, $\mathrm{TRT}=$ thoracic radiation therapy.

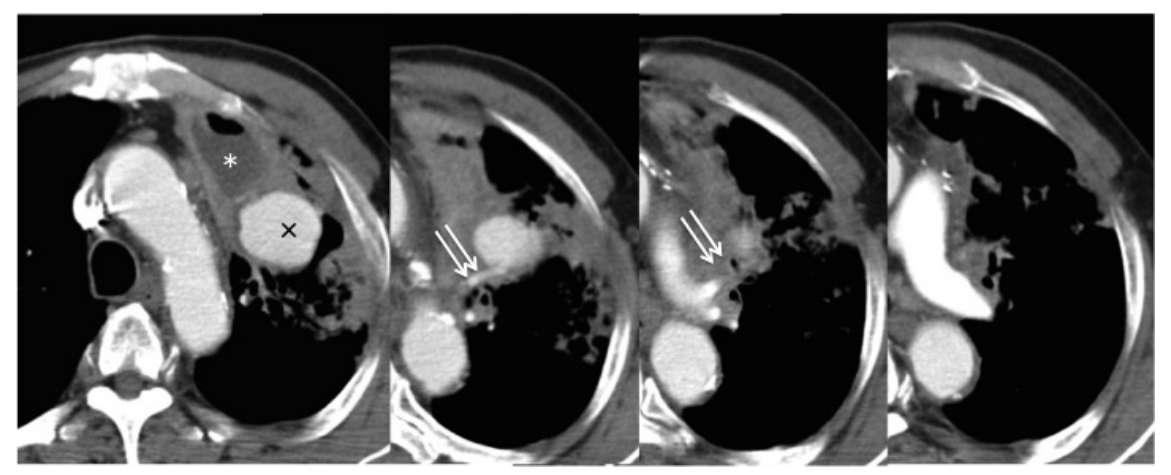



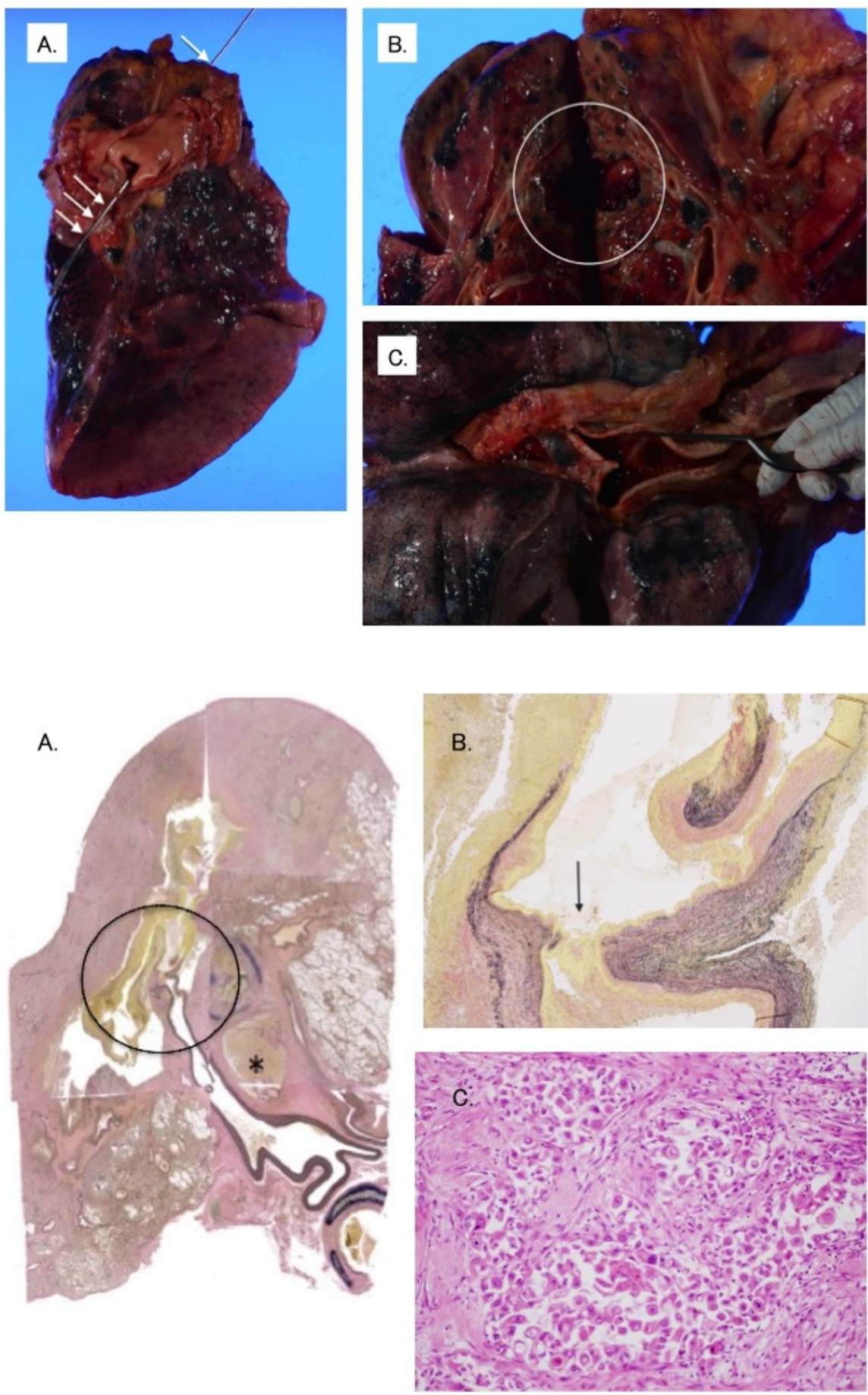